\title{
The Influence Of Honesty Cantine On Improvement Student Understanding About Anti-Corruption Values At SMPN 2 Cipunagara Subang
}

\author{
Arnie Fajar ${ }^{1)}$, Sopii ${ }^{2)}$, Lili Halimah ${ }^{3)}$ \\ ${ }^{1,3)}$ Masters Program in Social Sciences Education STKIP Pasundan Cimahi, West Java, Indonesia \\ 2) SMPN 1 Compreng, Subang Regency, West Java, Indonesia \\ Corresponding Author: Lili Halimah, Email: lili.halimah@gmail.com
}

\begin{abstract}
History: Received 28/12/2021 | Revised 02/01/2022 | Accepted 15/01/2021 | Published 31/01/2022
Abstract. The word corruption is covered almost every day by the mass media and has become a topic of discussion in various circles of society. Corruption is an extraordinary crime because it can affect the community, and in the long run, it is more dangerous for the younger generation's behavior. If conditions like that are allowed, the country's future will be very bleak. Therefore, it is necessary to instill anticorruption values through education to internalize anti-corruption values in various ways, one of which is through the application of an honesty canteen. The purpose of this study was to determine the effect of the honesty canteen in increasing students' understanding of anti-corruption values at SMPN 2 Cipunagara. The method used is quantitative with descriptive verification method. The population is 391 students with a sample of 78 students. The approach used is quantitative with a descriptive verification method.Data collection techniques through questionnaires, interviews, observation, and document analysis. Data analysis relies on statistical tests of questionnaire results which are supported by interviews, observations, and document analysis. The results showed that the honesty canteen development model had a significant effect on the culture of anti-corruption values. This is evidenced by finding a correlation coefficient (r) of 0895 which means that the degree of relationship between variable $\mathrm{X}$, namely honesty canteen, is very close and even perfectly related to variable $\mathrm{Y}$, namely understanding anti-corruption values. The magnitude of the significance in the regression analysis is $0.174>0.05$. The $\mathrm{t}$ value is $17.463>\mathrm{t}$ table 00003289 so it can be concluded that $\mathrm{H} 1$ is accepted, that is, there is an effect of $\mathrm{X}$ on $\mathrm{Y}$. And the R-square value of 0.800 in the analysis of the coefficient of determination, which means the effect of $\mathrm{X}$ on $\mathrm{Y}$ is seen as $80,0 \%$. This shows that the existence of honesty canteen activities in schools has a very positive impact on students' understanding of anticorruption values.
\end{abstract}

Keywords: Honesty Canteen; Anti-Corruption Values

Abstrak. Kata korupsi hampir setiap hari diliput oleh media massa dan menjadi perbincangan di berbagai kalangan masyarakat. Korupsi merupakan kejahatan yang tidak biasa (ekstra ordinary crime) karena dapat menimpa masyarakat dan dalam jangka panjang lebih membahayakan perilaku generasi muda. Jika kondisi seperti itu dibiarkan masa depan suatu negara akan sangat suram. Oleh karena itu perlu dilakukan langkah-langkah menanamkan nilai-nilai antikorupsi melalui pendidikan untuk menginternalisasikan nilai-nilai antikorupsi dengan berbagai cara salah satunya melalui penerapan kantin kejujuran. Tujuan dari penelitian ini adalah untuk mengetahui pengaruh kantin kejujuran dalam meningkatkan pemahaman siswa tentang nilai-nilai antikorupsi di SMPN 2 Cipunagara. Metode yang digunakan adalah kuantitatif dengan metode deskriptif verifikatif. Populasi adalah 391 siswa dengan sampel 78 siswa. Pendekatan yang digunakan adalah kuantitatif dengan metode deskriptif verifikatif. Teknik pengumpulan data melalui kuesioner, wawancara, observasi, dan analisis dokumen. Analisa data bertumpu kepada uji statistika hasil kuesioner yang didukung hasil wawancara, observasi, dan analisa dokumen. Hasil penelitian menunjukkan bahwa Model pengembangan kantin kejujuran berpengaruh signifikan terhadap budaya nilai-nilai anti korupsi. Hal ini dibuktikan dengan ditemukannya koefisien korelasi (r) sebesar 0895 yang berarti bahwa derajat hubungan antara variabel $\mathrm{X}$ yaitu kantin kejujuran sangat erat bahkan berhubungan sempurna dengan variabel $\mathrm{Y}$ yaitu pemahaman anti- nilai korupsi. Besarnya signifikansi dalam analisis regresi adalah 0,174>0,05 dan nilai t hitung $17.463>\mathrm{t}$ tabel 00003289 sehingga dapat disimpulkan bahwa H1 diterima yaitu terdapat pengaruh X terhadap Y. Dan nilai R square sebesar 0.800 pada analisis koefisien determinasi yang berarti pengaruh $\mathrm{X}$ terhadap $\mathrm{Y}$ sebesar $80,0 \%$. Hal ini menunjukkan bahwa adanya kegiatan kantin kejujuran di sekolah berdampak sangat positif terhadap pemahaman siswa terhadap nilai antikorupsi. Kata kunci: Kantin Kejujuran; Nilai-Nilai Antikorupsi 


\section{INTRODUCTION}

In almost every country, corruption is a crime, so talking about corruption is always interesting. First, corruption is called a crime because it affects the people and property of the state and must be used following the will of the people and the laws passed by the state.

2. Corruption is a social disease that destroys the country if it is not stopped immediately. Third, corruption is about people being picked and chosen from among educated and knowledgeable people and therefore should be regarded as role models for society (Kaaba, 2007).

Both in developed and developing countries, especially in active developing countries such as Indonesia, the phenomenon of corruption always appears in all lines of people's lives. The performance results of the Corruption Eradication Commission (KPK), which include data on handling corruption cases by the KPK, show 417 corruption cases by politicians and community leaders, including 274 DPRD participants, 21 governors and mayors. From 2004 to May 2020, the Regent and his representatives numbered 122 people (Suyatmiko, 2020).

However, although various efforts have been made in Indonesia to eradicate corruption, different institutions have carried out corruption in different ways (Setiadi, 2018). The effects of corruption include increasing the cost of living because consumers or the public ultimately bear the cost of bribes from entrepreneurs. This caused a substantial financial loss to the country. Weakening the authority of the government. This has led to various other crimes, including counterfeiting, smuggling, intimidation, and decreased quantity and quality of development. The government lost public support (Saptono., 2007).

In addition, corruption also impacts economic development by creating turmoil and high inefficiency. The culture of corruption destroys the civilization of the country, the economic system, and, even worse, the spirit of the country, especially the younger generation (Muliyawan, 2021).

Therefore, we need to act proactively through education and act in the form of oppressive regulations/laws. Educational institutions are strategic ways to convey good things and keep the younger generation free from corruption (Admin, 2020). Successful education can produce graduates who are pious, have mature personalities, have up-todate knowledge and achievements, have a sense of nationality, and have a global perspective (Anwar, 2021).

Anti-corruption education is essential. Because education is a conscious effort to change people's behavior, including students who become future leaders (today's students, tomorrow's leaders), hoping that the younger generation consciously does it. Build anticorruption values unique to anti-corruption 
and have an anti-corruption spirit and character (Dawn, 2018).

Anti-corruption education is a personalized education that aims to improve the nation's personality, which is very important to be taught to school students. Education creates an anti-corruption character that promotes honesty, perseverance, courage and responsibility, independence, simplicity, justice, and tolerance. (Komalasari \& Saripudin, 2015). Therefore, school institutions are expected to foster the anticorruption spirit of students, strengthen the spirit of the younger generation, and work honestly, responsibly, and fairly when the management is renewed in the future.

The formal education sector can play a role in meeting the needs of preventing corruption indirectly through two approaches, namely: 1) targeting students; and 2) using students to suppress the environment so that it is not permissive to corruption (BPKP, 2004).

Anti-Corruption Education in schools invites students to consciously build the mentality that corruption is a disease that harms themselves, society, and the nation's future (Darmawan, Kesuma, \& Permana, 2008). The strategy for implementing anticorruption education in schools is carried out by teaching students the conveyed anticorruption values.

Schools need to develop curricula to guide the implementation of anti-corruption education in schools. People's lives today are faced with increasing corruption cases. This can harm the younger generation and society and the life of the nation and state. Therefore, with the support of the community, the government must immediately implement an education plan that can foster an anticorruption spirit and ultimately act anticorruption (Dawn, 2018).

The addition of anti-corruption scores is carried out by integrating or entering anticorruption scores into related courses. Anticorruption class materials can later be added to Civics, Mathematics, Career Guidance, and Language subjects (Wibowo, 2012). In addition, it can be done through extracurricular activities such as scouting and creating/implementing an honesty canteen. The honesty canteen is a real laboratory to practice honesty so that students don't behave shamefully. Because honesty is part of the mandate, the value of honesty is an anticorruption character (Halimah, Fajar, \& Hidayah, 2021).

The honesty canteen is a tool to test students' honesty. The implementation of the honesty canteen is one of the efforts to increase students' spirituality in four aspects, namely awareness, truth, self-direction, and gratitude. However, based on the response of seller respondents, there is still an element of unwillingness when the income does not match the number of goods and becomes a loss. This means that the honesty canteen has not fully become a student's spiritual enhancer 
because many still use it by doing cunning things such as not paying or taking more change (Parhan, Astuti, Putri, Alia, \& Oktapiani, 2020).

This study uses the value-oriented theory of social rationality from Max Weber, based on the motivations and goals of the actors, who have different motivations and goals for their actions (Jones \& Saifuddin., 2003). The rationality of value-oriented social behavior is a theory related to research and analysis of school strategies in providing honesty values to students through the honesty canteen at SMPN 2 Cipunagara.

Students as individuals who consider honesty canteens where the value of honesty itself is already known by students through socialization of values and norms in society, family, several subjects at school (religious subjects, Pancasila education and so on) and also socialization of anti-corruption education from an early age that carried out by the Subang education office.

The novelty lies in the approach used, namely quantitative. Most of the research results related to anti-corruption are used as references using qualitative methods. Apart from that, the anti-corruption values used are based on a review of the economic, sociological, and legal dimensions. Research that is used as a reference for reviewing anticorruption values in general. How significant is the influence of the honesty canteen on increasing students' understanding of anticorruption values at SMPN 2 Cipunagara?

\section{RESEARCH METHODS}

This study used a quantitative descriptive approach with an explanatory survey method, conducted on large and small populations to seek explanations and relationships between variables (Sugiyono., 2010). This survey was conducted on many individuals or units of analysis to find facts or factual information about the behavioral symptoms of groups or individuals and use the results as planning or decision-making material

The data processing in this study used appropriate statistics for causal purposes. The explanation includes explanations, but the focus of research as associative explanatory research is to explain the relationship between variables.

This study aimed at showing the effect of an honest canteen on students' understanding of the level of anti-corruption at SMPN 2 Cipunagara. The population of this study was all students with a sample of grades 7, 8, and 9. The sampling technique in this study used a random sampling technique, namely random or random sampling. The tools used were surveys, interviews, and observations carried out when researchers are trained to perfect their findings. 


\section{DISCUSSION}

The Pattern of Honesty Canteen Development for Increasing Students' Understanding of Anti-Corruption Values at SMPN 2 Cipunagara.

The honesty canteen as one of the government's programs in instilling the nature of honesty for the younger generation has indeed received a positive response from the community. Now, the wider community agrees that establishing an "honesty canteen" in their midst is certainly necessary. The honesty canteen has no sellers and is unattended. Food or drinks are displayed in the canteen. A cash box in the canteen helps accommodate payments from those who buy food or drinks. (Sri Narwanti 2011) suggests that: The honesty canteen is a real example of the application of character values included in extracurricular activities in the education unit. So, through extracurricular activities, students can learn to understand values that can later influence and even shape the character of the students themselves according to the values implied in the extracurricular activities they participate in. So that extracurriculars held by educational units seem limited to ordinary extracurriculars and extracurriculars that have meaning to apply character values to students.

From the opinion above, it can be concluded that the honesty canteen is an implication of the application of character values, especially the honest character that the school instills in students from an early age.
Based on the results of the research that has been done, through interviews with 7 students and 4 teaching staff, it was stated that the honesty canteen can be developed because it has a positive impact on the growth of anticorruption values, where students can get used to from an early age from the small things that exist in the community. The surrounding environment, including shopping with honesty.

The correlation test is known to have a significant value of $0.000>0.05$, which means the level of relationship between the $\mathrm{X}$ variable, the existence of an honesty canteen, and students' anti-corruption values. While the value of the correlation coefficient (r) of 0.759 can be interpreted that the level of relationship between the $\mathrm{X}$ variable, namely the existence of an honesty canteen, is very strongly related to the $\mathrm{Y}$ variable, namely the growth of anticorruption values in students. The purpose of implementing an honesty canteen in schools is to create honest attitudes and behavior, instill discipline, a sense of responsibility, and develop a noble character for all school members (Phramantari, 2013).

Regression test can be seen that the significance value for the effect of $\mathrm{X}$ (Honest Canteen) on $\mathrm{Y}$ (Anti-corruption values) is $0.057>0.005$. The $\mathrm{t}$-count value is $6.161>\mathrm{t}$ table 0.000893 , so it can be concluded that $\mathrm{H} 1$ is accepted, which means there is an effect of $\mathrm{X}$ (honesty canteen ) to $\mathrm{Y}$ (Anti-Corruption Values). The data from the results of the linear 
regression analysis can be used as the basis for making decisions on the hypothesis in this study, namely the influence of the honesty canteen on the understanding of anticorruption values in students. Based on the concept of psychological development, at this age, students have started to think in an abstract direction and leading to making hypotheses. Students can distinguish the motivation behind an action and consider it. They already have a standard of good or bad that appears in actual moral behavior. Therefore, it is necessary to use optimally to instill and foster their mindset independently and responsibly (Byrnes, 2008).

The correlation coefficient is known to have an R-square value of 0.575 . This means that the effect of X1 (Honest Canteen) on Y (Anti-corruption Values). The magnitude of the impact of X1 (Honest Canteen) on Y (Anticorruption Values) is $57.50 \%$. Students' anticorruption values are directly felt by the school, especially the teaching staff, principals, and administrative staff.

The pattern of developing an honesty canteen, starting with the procurement of similar items to more complex items, can significantly impact the inculcation of anticorruption values. The more types of goods sold in the honesty canteen proportional to the increasing profits, the anti-corruption values in students will also increase. The honesty canteen is open, not guarded, how to pay it is put in a money box/place, and if there is change, the buyer takes it himself. Thus in the honesty canteen, students are touched by their awareness to learn and apply an honest and obedient attitude to themselves even though there is no supervising officer (Syaharuddin, 2009).

Supporting and Inhibiting Factors in the Development of an Honesty Canteen towards Increasing Students' Understanding of Anti-Corruption Values at SMPN 2 Cipunagara.

The implementation of the honesty canteen is not only involved in students, but all parties have the right to be involved, namely teachers, administrative staff and school guards. The teacher gives an example to be involved in the honesty canteen to become motivated to do it.

The supporting factors according to the results of interviews and observations in the field are as follows: the support from the school in the form of the availability of separate canteen building facilities from other canteens, the presence of outsiders who are willing to supply merchandise to the honest canteen, the enthusiasm of all students in play an active role in the honesty canteen.

Meanwhile, the inhibiting factors in the implementation of the honesty canteen are:

1. The lack of space available in the honesty canteen. 
2. Only measuring $2 \mathrm{~m} \times 3 \mathrm{~m}$ can hinder students' movement space and the limited space for storing goods.

3. The lack of suppliers of goods to the honest canteen.

4. The availability of goods in the honesty canteen.

Not every day, because the distance between the supplier and the school location is too far.

The results of this study are the efforts made by the school in running the honesty canteen as a strategy in teaching honesty values to students at SMK Pemuda Krian, namely in the form of:

1. Strategic placement of the honesty canteen with the aim of preventing fraudulent acts that will be committed by students when buying at the honesty canteen.

2. The existence of pamphlets containing words of encouragement to act honestly.

3. The existence of supervision in the operation of the honesty canteen through CCTV.

4. Involvement of students in the management of the honesty canteen.

5. Socialization to students about the importance of honesty canteen.

The existence of an honesty canteen can change students' attitudes to be more honest. The school's efforts in running the honesty canteen are actually able to encourage students to be honest when transacting in the honesty canteen (Maria \& Suyanto, 2016).
After knowing the supporting factors and inhibiting factors, the researcher finally suggested some inputs for the continuity and progress of the honesty canteen in schools, including the canteen management coordinating with the school in facilitating the honesty canteen by placing the canteen in a more strategic location and a wider building, outside parties in raising funds or procuring more varied types of goods, raising investment funds in the honesty canteen from the teachers, school principals, administrative staff and investors from outside the school, improving the management of the honesty canteen.

Students are involved in becoming administrators and managers of the honesty canteen by applying the principles of openness and honesty. Thus the principal capital of honesty canteen management is honest (People, 2008).

The significant effect of implementing the development of an honesty canteen on increasing students' understanding of anticorruption values at SMPN 2 Cipunagara

\section{Pearson Correlation Test Results}

The significance value of $0.00>0.05$ means that the level of relationship between variable $\mathrm{X}$, namely the existence of an honesty canteen, has an increased understanding of anti-corruption values. While the correlation coefficient ( $r$ ) of 0.895 can be interpreted that the level of relationship between variable $\mathrm{X}$, namely the existence of an honesty canteen, is 
very strongly and even perfectly related to variable $\mathrm{Y}$, namely understanding of anticorruption values in students.

The results of the Pearson Correlation analysis are in line with the opinion (Fajar, 2018) (Arnie Fajar, et al, 2018) that people's lives are currently faced with corruption cases that always appear before their eyes. This can damage the younger generation and the foundations of the life of the nation and state. Therefore, the government, with the support of the community, must immediately arrange an educational curriculum that is able to foster an anti-corruption spirit

Educational institutions have a big role in giving moral messages. Students' success is measured by the high and low grades and honesty, character, or character possessed. this is in line with (Syaharudin 2009) opinion that: Efforts to eradicate corruption in the long term will reap success if carried out with a combination of repressive, preventive, and integral education.

The establishment of an honesty canteen in schools is a means to form a positive mental attitude and honest personality among students and a fairly effective medium in developing a sense of responsibility in students as cadres of national leaders in the future.

From this explanation, it can be concluded that there is a positive contribution to an honesty canteen in increasing students understanding of anti-corruption values. The Honesty Canteen is a laboratory for applying anti-corruption personality values as outlined in school extracurricular activities. Through honesty canteen activities, students recognize and understand the values that influence and even shape their personality according to the values that have been instilled.

Thus extracurricular activities at school do not stop at ordinary extracurricular activities but are activities that mean applying anti-corruption values for students. (Narwanti, 2011 , p. 40). Values describe the desire to be good, have values, and influence the attitudes and behavior of people who have these values (Lawang, 2004).

\section{Linear Regression Test Results}

Schools can be prevented from acts of corruption as a means of educating future generations. After school, instilling an anticorruption character is expected to be an honest individual who will become a leader in the future. One of the efforts to prevent corruption before there is an intention (preventive) and there is an intention (preventive) not to commit immorality is by habituation.

The preventive approach is real action in preventing anti-corruption actions. This is in line with the material contained in the book the Financial and Development Supervisory Agency (2004), namely: The preventive approach is an effort to prevent corruption which is directed at minimizing the causes and opportunities of corruption, while the 
preventive strategy is directed at preventing corruption by eliminating or minimizing the causes or opportunities for corruption. One habituation as one of the real preventive actions carried out by schools is the existence of an open canteen. Prevention approaches and strategies are efforts to prevent corruption from reducing censorship and opportunities for corruption to arise (BPKP, 2002).

The results of the linear regression test analysis with a significant value of the effect of X (Honest Canteen) on Y (anti-corruption values) of $0.174>0.05$ and the $t$ value of $17.463>\mathrm{t}$ table 0.0003289 , so it can be concluded that $\mathrm{H} 1$ is accepted which means there is an effect of $\mathrm{X}$ (honesty cafeteria) to $\mathrm{Y}$ (Anti-Corruption Values). So the existence of an honesty canteen carried out by a positive influence as a preventive measure to foster anti-corruption values from an early age.

From the explanation above, the researcher can conclude that an honesty canteen has a positive effect on students' understanding of anti-corruption values. The higher the role of the honesty canteen operated in schools, the higher the students' knowledge of anti-corruption values. According to the study results, the effect of applying the honest form shows a high degree in determining student morale (Nyimas, 2016).

\section{Coefficient of Determination Test Results}

Based on the results of the analysis, it can be seen that the R-square value of 0.800 means that the effect of $\mathrm{X} 1$ (Honest Canteen) on Y (Anti-corruption Values). The magnitude of the impact of $\mathrm{X} 1$ (Honest Canteen) on $\mathrm{Y}$ (Anti-Corruption Values) is $80.0 \%$. This means that the existence of honest canteen activities in schools has a very positive effect on understanding anti-corruption values. The level of influence of $80.0 \%$ means that the influence is classified as strong. The role of the honesty canteen increases students' knowledge of anti-corruption values. The existence of Scout extracurricular activities and honesty canteens play an essential role in determining students' honesty values to achieve honest personalities (Fitra Aria, 2018).

In addition to the results of the analysis of the parameters above, which show a strong relationship and influence of the existence of an honesty canteen on students' understanding of anti-corruption values, it is also supported by the results of teacher questionnaires and field interviews. The positive influence between the existence of an honesty canteen with the level of understanding of student values.

The results of questionnaires and interviews with teachers and canteen managers show that the honesty canteen has a positive effect on the level of understanding of anticorruption values, which is indicated by the number of goods sold according to the amount of money collected. As long as the honest canteen is in the school, it has never 
experienced a loss and generates increasing profits.

The successful application of an integrated honesty canteen approach with a combination of prevention education and a comprehensive strategy is one of the efforts to eradicate corruption. The application of honesty canteens in schools is very important to develop the attitude of thinking and behavior of honest and responsible students who are the next generation of the nation. (Syaharuddin, 2009).

In terms of education, eradicating corruption is a preventive measure before there is an intention (pre-prevention) and an intention (preventing) not to commit acts of corruption. Thus the application of the honesty canteen is the implementation of anticorruption education (Dawn, 2018). From the results of the study in the form of distributing questionnaires and interviews conducted by researchers to a number of respondents, the results of the normality test of the data were obtained as follows.

\section{CONCLUSION}

The honesty canteen implies the application of personal values, namely honesty which the school instills in students from an early age. Based on the results of research that has been carried out, this honesty canteen can be developed because it has a positive impact on the development of anti-corruption values where students can get acquainted since childhood. Environment including honest shopping.

Honesty canteen as therapy for students to instill anti-corruption character in the school environment. However, it has several supporting and constraining factors. The supporting elements are (1) support from the school in terms of canteen facilities and infrastructure (2) support from outside parties in the form of suppliers of goods (3) the enthusiasm of students in conducting transactions in the canteen honestly. At the same time, the inhibiting factors are (1) the lack of space and location of the canteen (2) the lack of several suppliers of goods (3) the limited number of goods.

The results showed that the significance value was $0.00>0.05$. We can understand that the degree of relationship between the $\mathrm{X}$ variable, namely the existence of an honesty canteen, is related to students' better understanding of anti-corruption values. While the value of the correlation coefficient (r) of 0.895 , it can be understood that the degree of relationship between the $\mathrm{X}$ variable, namely the existence of an honesty canteen, has a very close relationship. In fact, it fits very well with the $\mathrm{Y}$ variable, namely the understanding of anti-corruption values among students. Therefore, schools must establish and develop honesty canteens to train students to practice and test their honesty and responsibility. 


\section{REFERENCES}

[1] Admin.

(2020,

Juni

20). dindik.jatimprov.go.id. Retrieved from pendidikan-anti-korupsi-sejak-dini: https://dindik.jatimprov.go.id/pak//blog/3/pe ndidikan-anti-korupsi-sejak-dini

[2] Anwar, R. (2021, Desember 7). Pendidikan Terpenting adalah Pembentukan Akhlak. Retrieved from www.suaramerdeka.com: https://www.suaramerdeka.com/pendidikan/ pr-042075298/prof-arief-rahmanpendidikan-terpenting-adalah-pembentukanakhla

[3] BPKP. (2002). Upaya Pencegahan dan Penanggulangan Korupsi pada Pengelolaan Pelayanan Masyarakat. Jakarta : BKPN. Tim Pengkajian SKPN .

[4] BPKP. (2004). Peranan-Sektor-PendidikanFormal-Terhadap-Kebutuhan-PencegahanKorupsi . Jakarta. Retrieved from http://www.bpkp.go.id/puslitbangwas/konten /576/04.05-Peranan-Sektor-PendidikanFormal-Terhadap-Kebutuhan-PencegahanKorupsi

[5] Byrnes, J. P. (2008). Piaget's theory. In M. M. Haith \& J. B. Benson (editors), Encyclopedia of Infant and Early Childhood Development (Vol. 2). New York, NY, USA: Elsevier.

[6] Darmawan, C., Kesuma, D., \& Permana, J. (2008). Korupsi danPendidikan Antikorupsi. Bandung: Pustaka Aulia Press.

[7] Fajar, A. (2018). Model Pengintegrasian Pendidikan Antikorupsi. Jakarta: Kemendibud.

[8] Fitra Aria, H. (2018). Implementasi Pendidikan Antikorupsi melalui Budaya Sekolah di SMAN 1 Tarik Kabupaten Sidoarjo. . Jogyakarta: Universitas Negeri Yogyakarta .

[9] Halimah, L., Fajar, A., \& Hidayah, Y. (2021, Juni). Pendidiian AntiKorupsi Mata Kuliah Pancasila: Tingkatan Dalam Memahami Kejujuran . Jurnal Pendidikan Kewarganegaraan, 5(1).

[10] Hasanah, N. (2019, November 5). pentingnyapenerapan-kantin-kejujuran-di-sekolah. Retrieved from www.kompasiana.com: https://www.kompasiana.com/norhasanah72 05/5dc08a4cd541df77182a1682/pentingnyapenerapan-kantin-kejujuran-di-sekolah.

[11] Jones, P., \& Saifuddin. (2003). Pengantar Teori-Teori Social: Dari Teori Fungsionalisme Hingga Post- Modernisme, (trj.). Jakarta: Pustaka.

[12] Ka'bah, R. (2007, Januari-Maret). KORUPSI DI INDONESIA . Jurnal Hukllm dan Pembanglunan, 37(1), 77-89. Retrieved from http://jhp.ui.ac.id/index.php/home/article/vie wFile/144/82

[13] Komalasari, K., \& Saripudin, D. (2015). Integration of Anti-Corruption Education in School's Activitie. . American Journal of Applied Sciences, 12(6), 445-451. Retrieved from https://doi.org/10.3844/ajassp.2015.445.45

[14] Lawang, R. M. (2004). Kapital Sosial: Dalam Perspektif Sosiologik. Jakarta.

[15] Maria, A. T., \& Suyanto, T. (2016). Strategi Sekolah Dalam Mengajarkan Nilai-Nilai Kejujuran Pada Siswa. Kajian Moral dan Kewarganegaraan, 3(4), 1121-1136. Retrieved Januari 5, 2022, from file:///C:/Users/pplst/AppData/Local/Temp/1 6752-20730-1-PB.pdf

[16] Muliyawan. (2021). www.pn-palopo.go.id. Retrieved from korupsi-dalam-pusaranpolitik-dan-budaya: https://www.pnpalopo.go.id/index.php/berita/artikel/220korupsi-dalam-pusaran-politik-dan-budaya

[17] Narwanti, S. (2011). Pendidikan karakter. Yogyakarta : Familia.

[18] Nyimas. (2016). Pengaruh Pelaksanaan Kantin Kejujuran dalam Membantuk Akhlak Siswa di SDN 114 Palembang. . Palembang: Jurnal UIN Raden Fatah .

[19] Parhan, M., Astuti, A., Putri, A. Y., Alia, D. S., \& Oktapiani, T. N. (2020, Mei). Kantin Kejujuran Sebagai Penguji Spiritual Mahasiswa Di Universitas Pendidikan Indonesia. Jurnal Pendididikan Ekonomi Indonesia, 1(2), 81-86. Retrieved Januari 5, 2022, from file://C:/Users/pplst/AppData/Local/Temp/2 4860-61351-2-PB.pdf

[20] Phramantari, W. .. (2013). Efektivitas Pelaksanaan Kantin Kejujuran dalam 
Pembinaan Karakter Jujur di SMKN 1 Sewon Bantul. . Jogyakarta: UNY.

[21] Rakyat, P. (2008, Januari 16). Menakar Kejujuran di Kantin Sekolah (Online). Retrieved from beta.pikiranrakyat.com: http://beta.pikiranrakyat.com/index.php/Men akar Kejujuran di Kantin Sekolah (Online)

[22] Saptono. (2007). Pendidikan Kewarganegaraan untuk SMP kelas VIII . Jakarta: Phibeta.

[23] Setiadi, W. (2018, November). KORUPSI DI INDONESIA (Penyebab, Bahaya, Hambatan dan Upaya Pemberantasan, Serta Regulasi) . LEGISLASI INDONESIA, 15(3), 249-262.

[24] Sugiyono. (2010). Metode Penelitian Kuantitatif Kualitatif dan $R \& D$. Bandung: Alfabeta .

[25] Suyatmiko. voices.transparaency.org. Retrieved from The Importance of Political Integrity In Indonesia.: https://voices.transparency.org/th e-importance-of-political-integrity- inindonesia-36b6daf38e 82

[26] Syaharuddin. (2009, Maret 6). Kantin Kejujuran Sebuah Alternatif Budaya Antikorupsi. Retrieved from syaharuddin.wordpress.com: http://syaharuddin.wordpress.com/Kantin Kejujuran Sebuah Alternatif Budaya Antikorupsi

[27] Wibowo, A. (2012). Pendidikan Karakter: Strategi Membangun Karakter Bangsa Berperadaban. . Yogyakarta: Pustaka Pelajar. 